\title{
RANCANG BANGUN MODEL BISNIS EKOWISATA GRASBERG PASCA TAMBANG
}

\author{
BUSINESS MODELS ARCHITECTURE OF GRASBERG TOURISM POST MINING
}

\author{
Edi Suryanto*)1, Arif Imam Suroso*), Rokhani Hasbullah $^{* *}$ \\ ${ }^{*}$ Sekolah Bisnis, IPB University \\ Jl. Pajajaran, Bogor 16151, Indonesia \\ ${ }^{* *}$ Departemen Teknik Mesin dan Biosistem, Fakultas Teknologi Pertanian, IPB University \\ Jl. Lingkar Akademik, Kampus IPB Darmaga, Bogor 16680, Indonesia
}

\begin{abstract}
Grasberg post mining land of PT Freeport Indonesia (PTFI) has the opportunity to become an attractive ecotourism location. The objectives of this study are (1) Analyze current business models. (2) Analyze internal and external factors that affect the post-mining Grasberg ecotourism business model. (3) Design a verified business model (BMC-1) by considering internal and external analysis. (4) Formulation of strategies and policy priorities for post-mining Grasberg ecotourism development. The research method used was AHP, $B M C$, PESTEL and VRIO. The results showed that the current business model with several initial indicators for each of the 9 elements of the block model. Internal factors that have a sustainable competitive advantage are location, tourism potential, supporting facilities and facilities, the ability to manage mining tourism, the ability to work in teams, the ability to produce innovation and creativity. External factors that affect the business model, political aspects are influenced by regime change which then affects the share ownership portion as well as cabinet changes as well as the security stability factor. The design of the WTG (Grasberg Mine Tourism) business model resulted in a verified BMC with the addition of indicators for the nine elements of the model. The priority of developing WTG policies focuses on alternative development of tourism services, participation of indigenous peoples, management of activities and coordination of indigenous peoples. The conclusion of this research is to be able to go to the commercial tourism industry, WTG managers need to focus on the key activity elements, the value proposition element, the key resource elements, and the key partner element.
\end{abstract}

Keywords: AHP, BMC, PESTEL, Post Mine Tourism, VRIO

\begin{abstract}
Abstrak: Lahan bekas tambang Grasberg PT Freeport Indonesia (PTFI) berpeluang menjadi lokasi ekowisata yang menarik. Tujuan dari penelitian ini adalah (1) Menganalisis model bisnis saat ini. (2) Menganalisis faktor internal dan eksternal yang memengaruhi model bisnis ekowisata Grasberg pasca tambang. (3) Merancang model bisnis terverifikasi (BMC-1) dengan mempertimbangkan analisis internal dan eksternal. (4) Perumusan strategi dan prioritas kebijakan pengembangan ekowisata Grasberg pasca tambang. Metode penelitian yang digunakan adalah AHP, BMC, PESTEL dan VRIO. Hasil penelitian didapatkan model bisnis saat ini dengan beberapa indikator awal pada setiap 9 elemen blok model. Faktor internal yang memiliki keunggulan kompetitif berkelanjutan adalah letak, potensi wisata, fasilitas dan sarana pendukung, kemampuan pengelolaan wisata tambang, kemampuan bekerja sama dalam tim, kemampuan menghasilkan inovasi dan kreativitas. Faktor eksternal yang memengaruhi model bisnis, aspek politik dipengaruhi adanya pergantian rezim yang kemudian memengaruhi porsi kepemilikan saham serta pergantian kabinet dan juga faktor stabilitas kemanan. Rancang bangun model bisnis WTG (Wisata Tambang Grasberg) menghasilkan BMC terverifikasi dengan penambahan indikator untuk kesembilan elemen model. Prioritas pengembangan kebijakan WTG menitikberatkan kepada alternatif pengembangan jasa wisata, partisipasi masyarakat adat, pengelolaan kegiatan dan koordinasi masyarakat adat. Kesimpulan dari penelitian ini adalah untuk dapat menuju ke industri pariwisata komersil maka pengelola WTG perlu berfokus kepada: elemen key activities, elemen value proposition dan elemen key resources, serta elemen key partner.
\end{abstract}

Kata kunci: AHP, BMC, PESTEL,VRIO, Wisata Bekas Tambang

\footnotetext{
${ }^{1}$ Alamat Korespondensi:

Email: esuryant@fmi.com
} 


\section{PENDAHULUAN}

PT. Freeport Indonesia (PTFI) merupakan perusahaan tambang emas dan tembaga terbesar di dunia yang beroperasi di Kecamatan Tembagapura Kabupaten Mimika. PTFI memulai operasi penambangan di Grasberg sejak tahun 1988. Tambang ini berlokasi terpencil di daerah pegunungan dengan ketinggian 4.200 mdpl. Grasberg aslinya bernama Wangmabuk, yang dalam bahasa Amungkal berarti bukit rumput (Muller dan Omabak, 2014). Penambangan di Grasberg telah berakhir tahun 2019. Pasca tambang Grasberg meninggalkan bekas lubang tambang dengan diameter $\pm 4 \mathrm{~km}$ dengan kedalaman $\pm 1 \mathrm{~km}$. Mempertimbangkan potensi jumlah sebaran penduduk lokal di 13 kampung serta tingkat pendidikan masyarakat lokal secara umum dalam kecamatan Tembagapura, maka ekowisata lahan bekas tambang menjadi alternatif pilihan menarik untuk pemanfaatan lahan pasca tambang. Business Model Canvas (BMC) adalah sebuah model bisnis yang menggambarkan dasar pemikiran tentang bagaimana organisasi menciptakan, memberikan, dan menangkap nilai. Kanvas ini membagi bisnis model menjadi sembilan buah komponen utama, kemudian dipisahkan lagi menjadi komponen kanan dan kiri. Dua komponen ini analoginya seperti mapping otak manusia, yaitu komponen kanan (otak kanan) dimana berfikir secara logis, rasional serta analitis untuk memulai ide dan komponen kiri (otak kiri) dimana ide-ide didapat secara acak, intuitif serta holistik (Osterwalder, 2010). Lingkup penelitian terbatas pada tahap rancang bangun model.

Beberapa penelitian pendahulu yang relevan dengan model bisnis kanvas ini adalah Strategi Pengembangan Bisnis Rental Mobil Wiralodra 27 Dengan Pendekatan Model Bisnis Kanvas (Agustiadi et al. 2018), Pola Pengelolaan Ekowisata Berbasis Masyarakat Di Gili Lawang Lombok Timur Nusa Tenggara Barat (Aziz et al. 2021), Model Bisnis Kanvas Docayam Kampung PT. PQR (Dewi et al. 2020), Developing Of BeachBased Ecotourism Area In The Sub-District Of Kelumbayan, Tanggamus Regency (Efendi, 2021), Karakteristik Pengunjung Ekowisata Pesisir Pantai Arung Buaya Desa Meliah Kecamatan Subi Kabupaten Natuna (Erianto et al. 2021), Kelayakan Sungai Seni Kobereh sebagai Obyek dan Daya Tarik Wisata Alam di Distrik Mare Selatan, Kabupaten Maybrat, Papua Barat (Hara et al. 2021), Nilai Ekonomi Ekowisata Mangrove Di Desa Margasari Kecamatan Labuhan Maringgai, Kabupaten Lampung Timur (Hartati et al. 2021), Strategi Pengembangan Balai Inseminasi Buatan Lembang Kabupaten Bandung Barat Dengan Pendekatan Business Model Canvas (Prabuwisudawan et al. 2018), Pengembangan Atraksi Ekowisata Mangrove Berbasis Masyarakat Di Kawasan Pesisir Desa Tateli Dua, Kab. Minahasa, Provinsi Sulawesi Utara (Pesik dan Lagarense, 2021), Jenis-Jenis Objek Ekowisata Dan Peran Kelompok Sadar Wisata (Pokdarwis) Nglanggeran dalam PengelolaanEkowisata di Desa Wisata Nglanggeran Kabupaten Gunungkidul (Rofiq et al. 2021), Studi Peluang Pengembangan Ekowisata Untuk Mendukung Keberlanjutan Kota (Studi Kasus: Kelurahan Medokan Ayu, Surabaya). Lab. Perancangan Kawasan dan Bangunan Arsitektur (Susanti et al. 2021). Identifikasi Potensi Pemanfaatan Ekowisata Dan Jasa Lingkungan Kabupaten Samosir (Simarmata et al. 2021), Potensi Pengembangan Ekowisata Solusi Matapencaharian Berkelanjutan Masyarakat di Desa Ketapang Raya Lombok Timur (Syukur et al. 2020), Pengembangan Objek Wisata Bukit Dami Dengan Konsep Ekowisata Di Desa Tigasan Wetan, Leces, Probolinggo (Widayanto, Mutinda Teguh. 2021). Pemasaran, Daya Tarik Ekowisata dan Minat Berkunjung Wisatawan (Widagdyo et al. 2021), Strategi Peningkatan Daya Saing Sektor Jasa Pariwisata Indonesia: Studi Kasus Jasa Pariwisata Danau Toba dan Bali (Widyastutik et al. 2020). Penelitian ini mengisi kekosongan penelitian tentang penerapan model bisnis kanvas untuk pemanfaatan lahan pasca tambang menjadi industri pariwisata di Indonesia.

Pendekatan penelitian ini adalah studi literatur, observasi langsung, wawancara untuk menganalisis model bisnis BMC dengan memindai 9 elemen dasar untuk memperoleh hipotesis BMC-0. Analisis lingkungan internal menggunakan kerangka VRIO dan eksternal menggunakan kerangka PESTEL. Hasil dari analisis internal dan ekternal adalah isu strategik yang dimanfaatkan untuk perbaikan dan penyusunan model bisnis terverifikasi (BMC-1). Penyusunan strategi dan prioritas pengembangan kebijakan pariwisata dengan analisis AHP melalui pendapat ahli.

Tujuan penelitian ini adalah (1) Menganalisis model bisnis saat ini; (2)Menganalisis faktor internal dan eksternal yang memengaruhi model bisnis ekowisata Grasberg Pasca Tambang; (3)Merancang model bisnis terverifikasi (BMC-1) dengan mempertimbangakan analisis internal dan eksternal; (4)Penyusunan strategi dan prioritas kebijakan pengembangan ekowisata Grasberg Pasca Tambang. 


\section{METODE PENELITIAN}

Lokasi penelitian adalah area Tambang Grasberg PTFI yang masuk dalam wilayah distrik Tembagapura Kabupaten Mimika. Waktu penelitian adalah bulan September 2020-Maret 2021. Data yang digunakan dalam penelitian ini adalah kombinasi data primer dan sekunder. Teknik pengambilan data menggunakan wawancara, kuesioner, observasi, dan Focus Group Discussion (FGD).

Teknik analisis data dalam penelitian ini dilakukan dalam 4 tahapan, (1) identifikasi 9 elemen BMC-0 untuk wisata tambang Grasberg saat ini, (2) analisis faktor internal dan eksternal yang memengaruhi model bisnis ekowisata Grasberg Pasca Tambang, (3)rancang bangun model bisnis (BMC-1), (4) pemilihan prioritas pengembangan kebijakan pariwisata dengan metode Analytic Hierarchy Process (AHP).

Kerangka pemikiran dapat dilihat pada Gambar 1 . Model bisnis hipotesis awal (BMC-0) dibangun untuk menjadi dasar rancang bangun model bisnis terverifikasi (BMC-1). Setelah BMC-0 didapatkan maka kemudian dilakukan analisis faktor internal dan eksternal yang memengaruhi model bisnis. Hasil dari analisis internal dan eksternal melahirkan isu strategik. BMC-1 dibangun berdasarkan isu strategik dan hasil analisis internal-eksternal. Untuk mendukung BMC-1 maka dilakukan analisis pemilihan prioritas pengembangan kebijakan menggunakan metode Analisis Hirarki Proses (AHP). Implikasi manajerial diperoleh dengan menggabungkan hasil analisis AHP dan BMC-1.

\section{HASIL}

\section{Model Bisnis Hipotesis (BMC-0)}

Dari data 32 responden pengunjung WTG serta interview terhadap internal stakeholders PTFI didapatkan model BMC-0. Elemen customer segmen, belum adanya segmentasi pelanggan. Elemen value proposition, masih terbatas mengeksplorasi keindahan alam. Elemen channels, menggunakan saliran komunikasi internal. Elemen customer relationships, mengedepankan komunikasi personal dan komunitas. Elemen revenue streams, belum masuk ke ranah komersil masih sebatas menggunakan internal account PTFI. Elemen key resources, memiliki sumberdaya fisik dan fasilitas, sumberdaya intelektual dan sumberdaya manusia. Elemen key activities, WTG melakukan kegiatan jasa wisata dan pemeliharaan fasilitas di overlook Bunaken. Elemen key partner, pengelola WTG saat ini hanya menjalin kerjasama dengan internal departemen Quality of life PTFI untuk menjaring pelanggan. Elemen cost structure, biaya operasional kegiatan seperti biaya pemeliharan fasilitas infrastruktur serta biaya teknis lainnya.

\section{Faktor Internal dan Eksternal}

Faktor internal yang memiliki economic implications above normal dan memengaruhi model bisnis WTG adalah letak/lokasi, potensi wisata, fasilitas dan sarana pendukung, kemampuang pengelolaan wisata tambang, kemampuan bekerjasama dalam tim, kemampuang menghasilkan inovasi dan kreativitas.

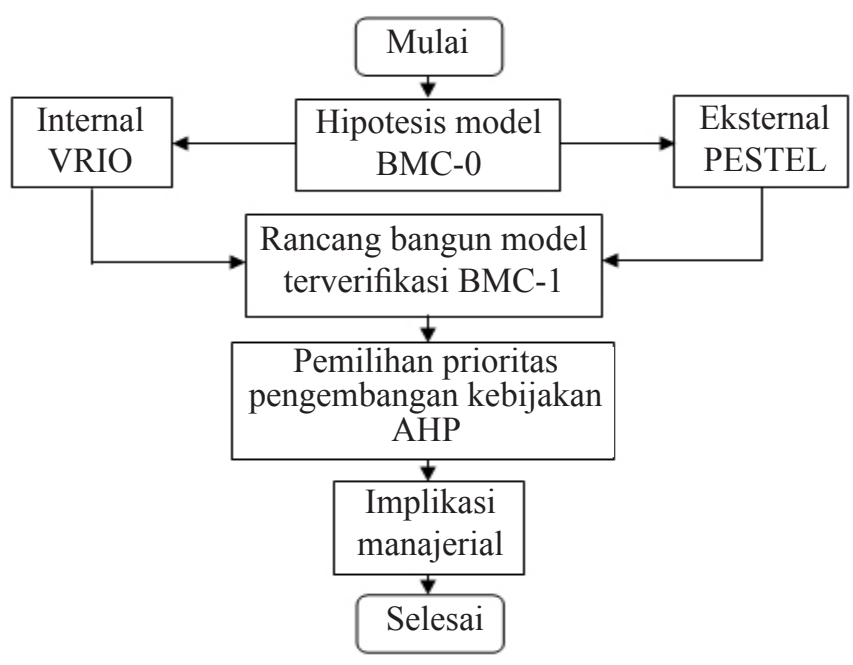

Gambar 1. Kerangka pemikiran penelitian 
Faktor eksternal yang memengaruhi model bisnis WTG adalah elemen politik, adanya divestasi saham PTFI oleh rezim pemerintahan Joko Widodo dan pergantian Menparekraf Kabinet Indonesia Maju yang kemudian mengubah arah kebijakan. Elemen ekonomi, pertumbuhan ekonomi Indonesia kuartal I - kuartal III tahun 2020 masih mengalami kontraksi(minus) 2,03\% sehingga berdampak kepada industri pariwisata. Elemen sosial budaya, Kemajemukan suku dan budaya disekitar Grasberg serta adanya Yayasan Pengembangan Masayarakat Amungme dan Kamoro (YPMAK). Elemen teknologi, Komitmet PT. Telkom untuk mengembangkan jaringan komunikasi di wilayah pegunungan tengah Papua. Elemen lingkungan, bentang alam pegunungan Jaya Wijaya dan potensi ancaman subsidence akibat penambangan GBC. Elemen legal, Adanya Peraturan Presiden Republik Indonesia Nomor 21 Tahun 2016 Tentang Bebas Visa Kunjungan dan Peraturan Daerah Propinsi Papua Barat nomor 14 tahun 2013 tentang Rencana Induk Pembangunan Kepariwisataan Daerah Tahun 20132033.

Dari analisis internal dan eksternal kemudian diperoleh isu strategik. Isu strategik yang diperoleh adalah perluasan customer segments serta pemilihan value proposition yang tepat untuk menjawab ekspektasi pelanggan, Penguatan channel pemasaran serta penambahan customer relationships serta key partnerships, Optimalisasi key resources dan key activities, Identifikasi dan alokasi revenue stream dan cost structure.

\section{Model Bisnis Terverifikasi (BMC-1)}

Setelah diperoleh isu strategik kemudian dilakukan perbaikan model bisnis menjadi BMC-1 (Gambar 2). Elemen customer segmen, segmentasi pasar diperlukan agar pengelola dapat memberikan value proposition sesuai kebutuhan pelanggan. Pembuatan paket wisata edukasi di sekolah-sekolah yang ada di regional Papua dan sekitarnya sekaligus dapat menanamkan tentang pentingnya menjaga kelestarian alam pasca penambangan berakhir. Paket wisata mountain adventure juga menjapi pilihan menarik yang didalamnya ada aktifitas perkemahan, mountain bike dengan memanfaatkan track area reklamasi KotekaKaimana.
Elemen value proposition, Berdasarkan hasil wawancara kepada pengunjung WTG dan masyarakat setempat, Pengunjung berharap ada penambahan fasilitas umum untuk kenyamanan wisatawan saat berlibur. Penambahan fasilitas yang diharapkan antara lain Papan informasi (rute), Ketersediaan air bersih yang memadai, Energi listrik untuk pemanas suhu ruangan maupun untuk memanaskan air minum, Ketersediaan jaringan telephone 4G, Pembuatan area bumi perkemahan, Pembuatan mountain bike track di area Koteka Kaimana reklamasi, Penambahan wisata budaya lokal dengan melibatkan budaya suku terdekat area Grasberg. Penambahan fasilitas serta keterlibatan positif masyarakat setempat diharapkan dapat menjadi nilai tambah bagi WTG.

Elemen channels, untuk menambah jumlah pengunjung harus dilakukan promosi ke eksternal. Promosi harus terus ditingkatkan bahkan sampai tingkat mancanegara atau seluruh dunia. Hasil wawancara terhadap stakeholder WTG mengatakan bahwa diperlukan saluran promosi dengan memanfaatkan website resmi dan media sosial untuk menjaring pelanggan baik domestik maupun internasional yang lebih luas.

Elemen customer relationships, hasil observasi, pengisian kuesioner, dan wawancara diperlukan pendataan pengunjung. Data yang diperlukan dari pengunjung berupa nama, alamat lengkap, email dan nomor telepon. Hal ini memudahkan pengelola WTG dan agen travel mitra untuk mempromosikan paket wisata. Pengarsipan terhadap program komunitas juga diperlukan untuk menjaga hubungan dengan pelanggan tetap maupun calon pelanggan lainnya. Pemanfaatan teknologi informasi untuk pengelolaan alamat website resmi yang up to date untuk menyajikan kenyamanan bagi calon wisatawan untuk memperoleh informasi yang lebih akurat sangat diperlukan ketika menuju sebuah industri pariwisata yang profesional. Pembangunan loyalitas pelanggan melalui promo wisata spesifik juga diperlukan untuk menjaga stabilitas pengunjung.

Elemen revenue stream, porsi APBD diharapkan ikut menyumbang porsi modal. Pengelola WTG juga dapat memperoleh ruang iklan atau pun penjualan produk souvenir lokal untuk mempromosikan suatu produk lokal konten. Keterlibatan masyarakat lokal setempat dalam menyajikan sebuah atraksi budaya lokal tentunya menjadi arus pendapatan tersendiri. 


\begin{tabular}{|c|c|c|c|c|}
\hline \multirow[t]{2}{*}{$\begin{array}{l}\text { Key Partners } \\
\text { Departemen Quality of Life } \\
\text { PTFI. } \\
\text { - Pemda Mimika. } \\
\text { - YPMAK. } \\
\text { - Kodam Cenderawasih. } \\
\text { - Telkomsel. }\end{array}$} & $\begin{array}{l}\text { Key Activities } \\
\text { - Pelayanan dan pemeliharaan } \\
\text { tempat wisata tambang } \\
\text { Grasberg overlook Bunaken. } \\
\text { - Pemeliharaan fasilitas umum. } \\
\text { - Pembinaan wisata budaya } \\
\text { lokal. } \\
\text { - Penyelenggaraan wisata } \\
\text { adventure(Mountain bike, } \\
\text { Camp area, Mountain } \\
\text { tourism) }\end{array}$ & \multirow{2}{*}{ 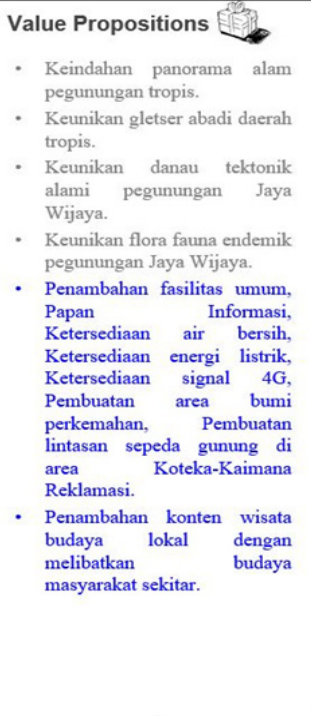 } & 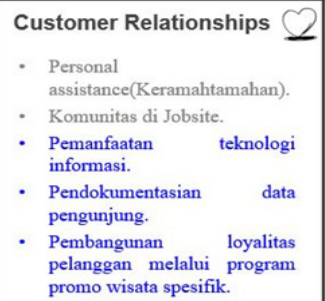 & \multirow[t]{2}{*}{$\begin{array}{l}\text { Customer Segments } \\
\text { - Wisatawan domestik dan } \\
\text { internasional dari lingkungan } \\
\text { internal maupun eksternal } \\
\text { PTFI. } \\
\text { - Paket wisata edukatif bagi } \\
\text { pelajar dan mahasiswa. } \\
\text { - Paket wisata mountain } \\
\text { adventure bagi segment } \\
\text { pasar khusus. }\end{array}$} \\
\hline & $\begin{array}{l}\text { Key Resources } \\
\text { - Sumberdaya fisik/keindahan } \\
\text { alam dan fasilitas. } \\
\text { - Sumberdaya } \\
\text { Intelektual(Brand). } \\
\text { - Sumberdaya } \\
\text { manusia(Pengelola). } \\
\text { - Kemampuan pengelolaan } \\
\text { WTG. } \\
\text { - Kemampuan bekerjasama } \\
\text { dalam tim. } \\
\text { - Kemampuan menghasilkan } \\
\text { inovasi dan kreatifitas. } \\
\text { - Kompetensi Standar } \\
\text { Pariwisata SDM(SKKNI). }\end{array}$ & & $\begin{array}{l}\text { Channels } \\
\text { - Komunikasi langsung melalui } \\
\text { mitra. } \\
\text { - Pemanfaatan IT, Sosial } \\
\text { Media, Website, Pembuatan } \\
\text { Aplikasi Android. }\end{array}$ & \\
\hline \multicolumn{5}{|c|}{ 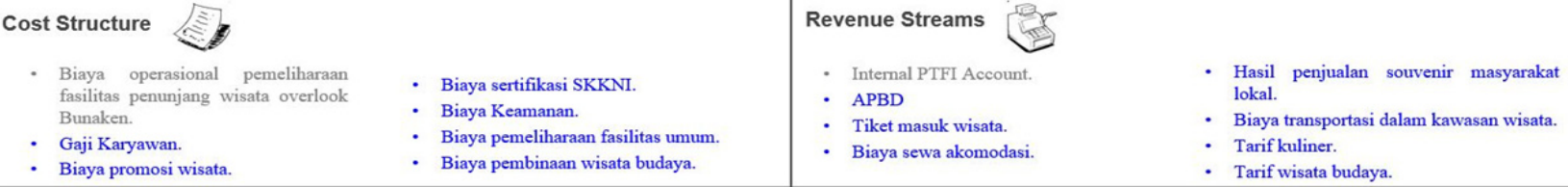 } \\
\hline
\end{tabular}

Gambar 2. BMC-1

Elemen key resources, hasil analisis VRIO untuk elemen kapabilitas internal memiliki economics implications Above Normal diantaranya adalah Kemampuan pengelolaan WTG, Kemampuan bekerjasama dalam tim, Kemampuan menghasilkan inovasi dan kreatifitas. Pengelola WTG dihadapkan pada kondisi dimana tingkat pendidikan masyarakat lokal masih kurang dari yang diharapkan untuk dapat menjalankan WTG dengan baik, hal ini menjadi kendala ketika pengelola WTG mendorong keterlibatan aktif masyarakat lokal dalam pengelolaan wisata budaya. Pandangan berbasis sumber daya merupakan aspek penting dari bidang model bisnis (Hedman dan Kalling 2003). Hasil analisis VRIO untuk elemen sumberdaya manusia pengelola WTG juga menunjukkan tidak ditemukan sumberdaya manusia dengan latar belakang pendidikan pariwisata, kebanyakan adalah lulusan teknik. Pihak pengelola WTG harus berani melakukan investasi sumber daya manusia untuk keberlanjutan perkembangan ekowisata Grasberg pasca tambang melalui sertifikas standar kompetensi(SKKNI) yang relevan.

Elemen key activities, adanya value proposition penambahan fasilitas umum dan penambahan konten wisata budaya maka berdampak terhadap key activities yaitu Pemeliharaan fasilitas umum tersebut serta pembinaan wisata budaya lokal.
Elemen key partner, berdasarkan analisis PESTEL untukvariabelPolitik, Sosial,Teknologi,makadiperlukan penambahan partner kunci dalam menjalankan operasional, yaitu Pemda Mimika, YPMAK, Kodam Cenderawasih dan Telkomsel. Pemda Mimika selaku pemegang $10 \%$ pemegang saham pemerintah jelas memiliki andil serta alokasi APBD yang diperlukan. YPMAK selaku lembaga pemberdayaan masyarakat adat tentu memiliki peran penting dalam menjamin keterlibatan masyarakat untuk konten wisata budaya lokal. Kodam Cenderawasih memiliki peran besar dalam menjaga stabilitas keamanan wilayah. Telkomsel selaku penyedia layanan jasa telekomunikasi memiliki peran penting menjamin kelancaran arus informasi.

Elemen cost structure, berdasarkan analisis internal dan eksternal, maka didapatkan beberapa penambahan indikator cost structure, yaitu gaji karyawan, aktivitas promosi, biaya sertifikasi SKKNI, biaya keamanan, biaya pemeliharaan tambahan fasilitas umum, biaya pembinaan wisata budaya. Diperlukan dedicated karyawan yang bertugas mengelola WTG secara komersil yang tentunya membutuhkan alokasi anggaran untuk penggajian. Pemanfaatan teknologi informasi untuk kepentingan promosi produk wisata tentu juga membutuhkan alokasi anggaran. Kondisi sumberdaya manusia yang memerlukan peningkatan kompetensi melalui sertifikasi SKKNI bidang kepariwisataan tentu membutuhkan alokasi dana khusus pengembangan 
sumberdaya manusia. Keterlibatan Kodam Cenderawasih dalam pengamanan regional Grasberg tentu akan mengambil anggaran pos keamanan. Bertambahnya fasilitas umum yang dibangun juga mengakibatkan alokasi anggaran tambahan untuk pemeliharaan. Pembinaan wisata budaya lokal juga jelas akan memerlukan biaya baik bersifat tangible maupun intangible.

\section{Strategi dan Prioritas Pengembangan Kebijakan}

Hierarki pemilihan prioritas pengembangan kebijakan pariwisata didasarkan pada UU No 10 Tahun 2009 tentang Kepariwisataan:

Level aktor, menduduki prioritas pertama terhadap pengambilan kebijakan pengembangan WTG adalah PTFI dengan bobot 0,83333 dan konsistensi rasio 0. Mayoritas narasumber berpendapat bahwa IUPK masih dipegang PTFI sampai dengan tahun 2041 sehingga PTFI lah aktor prioritas yang akan mengambil kebijakan strategis.

Level faktor, menduduki prioritas pertama terhadap pengambilan kebijakan pengembangan WTG adalah Industri Pariwisata dengan bobot 0,43064 dan konsistensi rasio 0,08062 . Faktor kedua yang menjadi prioritas adalah Destinasi Pariwisata dengan bobot nilai sebesar 0.24587 . Faktor ketiga yang menjadi prioritas adalah Pemasaran Pariwisata dengan bobot nilai sebesar 0.18892 dan Faktor keempat yang menjadi prioritas adalah Kelembagaan Pariwisata dengan bobot nilai sebesar 0.13458 .

Level kriteria, pada masing-masing faktor yang memengaruhi pengembangan prioritas kebijakan Ekowisata Grasberg Pasca Tambang dengan nilai konsistensi rasio berkisar dari 0.08062-0.09524 maka untuk kriteria dalam faktor Industri Pariwisata, yang menjadi prioritas utama menurut para ahli dalam penelitian ini adalah Tanggung jawab terhadap lingkungan alam dan sosial budaya dengan bobot nilai 0.29509 pada posisi pertama, kemudian Daya saing produk wisata dengan bobot nilai 0.06745 , Kemitraan usaha pariwisata dengan bobot nilai 0.03851, Kredibilitas bisnis pariwisata dengan bobot nilai 0.02959. Untuk faktor Destinasi Pariwisata, adapun kriteria yang menjadi prioritas utama menurut para ahli dalam penelitian ini adalah Pemberdayaan Masyarakat dengan bobot nilai 0.13303 , Pembangunan fasilitas terpadu dan berkesinambungan dengan bobot nilai
0.04921, Pembangunan Prasarana dengan bobot nilai 0.03152 , Pembangunan daya tarik pariwisata dengan bobot nilai 0.02019, dan Penyediaan fasilitas umum dengan bobot nilai 0.1191. Untuk faktor Pemasaran Pariwisata, adapun kriteria yang menjadi prioritas utama menurut para ahli dalam penelitian ini adalah Pemasaran pariwisata yang bertanggungjawab dengan bobot nilai 0.11757 , Pemasaran pariwisata terpadu dengan bobot nilai 0.03814 , Pemasaran pariwisata berkesinambungan dengan bobot nilai 0.02181 , dan Pemasaran pariwisata bersama dengan bobot nilai 0.1139. Untuk faktor Kelembagaan Pariwisata, adapun kriteria yang menjadi prioritas utama menurut para ahli dalam penelitian ini adalah Masyarakat dengan bobot nilai 0.05214 , Pengembangan SDM dengan bobot nilai 0.02114 , Pemerintah daerah dengan bobot nilai 0.02078 , Pengembangan organisai pemerintah dengan bobot nilai 0.01742 , Swasta dengan bobot nilai 0.01019 , Regulasi dengan bobot nilai 0.00684 dan Mekanisme operasional dengan bobot nilai 0.00607 .

Level alternatif, Adapun nilai konsistensi rasio sebesar 0.00191-0.09964 maka dapat dipastikan data tersebut valid untuk digunakan. Untuk faktor Industri pariwisata, Alternatif yang menjadi prioritas utama adalah Jasa Wisata dengan bobot nilai 0.15072 , Kuliner dengan bobot nilai 0.13087, Pusat Perbelanjaan dengan bobot nilai 0.05201 , Industri Keratif dengan bobot nilai 0.0495 dan Perhotelan dengan bobot nilai 0.04754. Sedangkan untuk faktor Destinasi Pariwisata, Alternatif utama yang sebaiknya diprioritaskan adalah Partisipasi Masyarakat dengan bobot nilai 0.08024 , Fasilitas Kesehatan dengan bobot nilai 0.08018 , Telekomunikasi dengan bobot nilai 0.04164 , Transportas dengan bobot nilai 0.02512 dan Kualitas jalan dengan bobot nilai 0.01869. Untuk faktor Pemasaran Pariwisata, Alternatif utama dan prioritas adalah Pengelolaan Kegiatan dengan bobot nilai 0.11384, Branding dengan bobot nilai 0.05951, dan Website resmi dengan bobot nilai 0.01556. Faktor Kelembagaan Pariwisata memiliki alternatif utama dan prioritas adalah Koordinasi Masyarakat Adat dengan bobot nilai 0.09833, Peraturan Daerah dengan bobot nilai 0.02536 dan Organisasi Pariwisata dengan bobot nilai 0.0109 .

\section{Implikasi Manajerial}

Penelitian "Rancang Bangun Model Bisnis Ekowisata Grasberg Pasca Tambang" dibuat sebagai alternatif pemanfaatan lahan pasca tambang Grasberg. Hasil analisis AHP mengatakan bahwa prioritas alternatives 
pengembangan kebijakan WTG untuk faktor Industri Pariwisata adalah JasaWisata.Alternatives inimembawa implikasi bahwa untuk dapat mengembangkan WTG maka perlu berfokus kepada elemen key activities di BMC-01, yaitu pelayanan dan pemeliharaan tempat wisata tambang Grasberg overlook Bunaken, Pemeliharaan fasilitas umum, Pembinaan wisata budaya lokal, Penyelenggaraan wisata adventure(Mountain bike, Camp area, Mountain tourism).

Prioritas alternatives pengembangan kebijakan WTG untuk faktor Destinasi Pariwisata adalah Partisipasi Masyarakat Adat. Alternatives ini membawa implikasi bahwa untuk dapat mengembangkan WTG maka perlu berfokus kepada elemen value proposition di BMC-01, yaitu penambahan konten wisata budaya lokal dengan melibatkan budaya masyarakat sekitar.

Prioritas alternatives pengembangan kebijakan WTG untuk faktor Pemasaran Pariwisata adalah Pengelolaan Kegiatan. Alternatives ini membawa implikasi bahwa untuk dapat mengembangkan WTG maka perlu berfokus kepada elemen key resources di BMC-01, yaitu Kemampuan pengelolaan WTG, Kemampuan bekerjasama dalam tim, Kemampuan menghasilkan inovasi dan kreatifitas, Kompetensi Standar Pariwisata $\operatorname{SDM}(\mathrm{SKKNI})$. Prioritas alternatives pengembangan kebijakan WTG untuk faktor Kelembagaan Pariwisata adalah Koordinasi Masyarakat Adat. Alternatives ini membawaimplikasibahwauntukdapatmengembangkan WTG maka perlu berfokus kepada elemen key partner di BMC-01, yaitu melibatkan YPMAK sebagai bentuk perwakilan lembaga masyarakat adat.

\section{KESIMPULAN DAN SARAN}

\section{Kesimpulan}

Model bisnis saat ini (BMC-0) mendapatkan beberapa indikator awal dalam setiap elemen blok model. Customer segment, belum ada segmentasi pelanggan. Value proposition, Terbatas pada keindahan dan keunikan alam. Channel, komunikasi langsung melalui mitra. Customer relation, mengandalkan komunitas di Jobsite. Revenue stream, masih mengandalkan internal account PTFI. Key resources, masih menggunakan sumberdaya belum kapabilitas. Key activities, hanya berfokus dikegiatan wisata overlook Bunaken. Key partner, mengandalkan departemen QoL di lingkungan internal PTFI. Cost structure, masih terfokus di beaya pemeliharaan destinasi overlook Bunaken belum menyentuh sektor lain.

Faktor internal yang memiliki economics implications dengan kategori above normal adalah lokasi(strategis dan keramahan masyarakat sekitar), jumlah potensi wisata(spot wisata dan keunikan), kelengkapan fasilitas danprasaranpendukung,kemampuanpengelolaanwisata tambang(kelestarian, kebersihan dan kerapihan tempat wisata), kemampuan bekerjasama dalam tim(saling mendukung), kemampuan menghasilkan inovasi dan kreatifitas(mengatasi hambatan dan mengoptimalkan peluang). Faktor eksternal yang memengaruhi model bisnis WTG adalah variabel politik dengan beralihnya kepemilikan porsi saham PTFI serta perombakan kabinet Indonesia Maju periode 2019-2024 yang berdampak terhadap arah kebijakan kemenparekraf. Variabel ekonomi adalah adanya pertumbuhan negatif terhadap perekonomian baik nasional maupun global adalah dampak dari sebaran pandemik Covid-19. Variabel sosial adalah keberadaan berbagai macam suku dan budaya serta adaanya yayasan lembaga masyarakat adat. Variabel teknologi adalah komitmen Telkomsel yang terus bekerjasama dengan pemerintah daerah untuk terus mengembangkan jaringan komunikasi di pegunungan tengah Papua. Variabel lingkungan adalah alam pegunungan Jaya Wijaya yang dapat dioptimalkan dalam mengembangkan ekosiwata Grasberg pasca tambang. Variabel legal adalah adanya Peraturan Presiden Republik Indonesia Nomor 21 Tahun 2016 Tentang Bebas Visa Kunjungan dan Peraturan Daerah Propinsi Papua Barat nomor 14 tahun 2013 tentang Rencana Induk Pembangunan Kepariwisataan Daerah Tahun 2013-2033 yang didalamnya tertuang rencana jangka panjang pembangunan industri pariwisata dalam kurun waktu 20 tahunan.

Rancang bangun model bisnis baru BMC-1 yang direkomendasikan dari penelitian ini yaitu untuk elemen customer segment, perlu dibuat paket wisata edukatif bagi pelajar dan mahasiswa, paket wisata mountain adventure. Elemen value proposition, perlu dibangun fasilitas umum serta penambahan konten wisata budaya lokal. Elemen channel, diperlukan pemanfaatan teknologi informasi untuk mengirimkan informasi produk kepada pelanggan. Elemen customer relationship, pemanfaatan teknologi informasi untuk pengelolaan database pelanggan serta membangun loyalitas pelanggan. Elemen revenue streams, sumber finansial dari APBD, tiket, biaya sewa, tarif. Elemen key resources, perlu melakukan standarisasi kompetensi 
dasar SKKNI bidang pariwisata. Elemen key activities, pembinaan wisata budaya lokal serta penyelenggaraan tourism adventure. Elemen key partnership, diperlukan keterlibatan Pemda, YPMAK, Kodam Cenderawasih, Telkom. Elemen cost structure, perlu pengalokasian biaya untuk sertifikasi kompetensi dasar pariwisata, biaya kemanan, biaya pembinaan wisata budaya lokal, biaya promosi, biaya pemeliharaan fasilitas dan gaji karyawan.

Prioritas strategi kebijakan pengembangan WTG menitikberatkan kepada alternatives pengembangan jasa wisata, partisipasi masyarakat adat, pengelolaan kegiatan, koordinasi masyarakat adat. Pengembangan ekowisata Grasberg Pasca Tambang kearah komersial hendaknya memprioritaskan alternatif jasa wisata untuk dikembangkan daripada alternatif perhotelan, kuliner, pusat perbelanjaan dan industri kreatif. Jasa wisata yang dimaksud adalah lebih fokus kepada elemen key activities, yaitu pelayanan dan pemeliharaan tempat wisata tambang Grasberg overlook Bunaken, pemeliharaan fasilitas umum, pembinaan wisata budaya lokal, penyelenggaraan wisata adventure (Mountain bike, Camp area, Mountain tourism). Partisipasi masyarakat adat juga menjadi prioritas dalam pengembangan ekowisata dalam elemen key activities dengan penyelenggaraan wisata budaya lokal. Pemasaran pariwisata menitikberatkan kepada alternatif pengelolaan kegiatan dibandingkan branding dan pemanfaatan website resmi. Pengelolaan kegiatan yang dimaksud adalah lebih kepada pengelolaan bisnis secara keseluruhan yang ada di model BMC-1 sebagai bagian dari pemasaran langsung. Bidang kelembagaan pariwisata prioritas pengembangan kebijakan lebih kepada koordinasi masyarakat adat yaitu ada di elemen key partnership melalui keterlibatan YPMAK sebagai perwakilan lembaga masyarakat adat Amungme dan Kamoro.

\section{Saran}

Melengkapi hasil penelitian yang telah dilakukan maka saran yang diberikan terkait implementasi ekowisata Grasberg pasca tambang adalah perlunya penelitian lanjutan terkait aspek manajemen finansial serta feasibility study. Manajemen finansial yang dimaksud meliputi tiga hal yaitu keputusan investasi (investment decision), keputusan pendanaan (finance decision), keputusan dividen (dividen decision). Penelitian tentang feasibility study meliputi aspek hukum, sosial budaya, pasar dan pemasaran juga diperlukan untuk memperkuat penelitian rancang bangun model bisnis ini sehingga harapannya akan menjadi kajian utuh terkait pemanfaatan lahan pasca tambang Grasberg untuk kepentingan industri pariwisata kedepannya.

\section{DAFTAR PUSTAKA}

Agustiadi A, Syarief R, Nurrochmat RD. 2018. Strategi pengembangan bisnis rental mobil Wiralodra 27 dengan pendekatan model bisnis kanvas. Jurnal Aplikasi Manajemen dan Bisnis 4(1):138-150. http://doi.org/10.17358/jabm.4.1.138

Aziz MK et al. 2021. Pola pengelolaan ekowisata berbasis masyarakat di gili lawang lombok timur nusa tenggara barat. Jurnal Hutan Tropika (Tropical Forest Journal) 17(2):138-149.

Dewi AH, Sukardi, Fahim TM. 2020. Model bisnis kanvas doc ayam kampung PT. PQR. Jurnal Aplikasi Manajemen dan Bisnis 6(1):188-196. http://doi.org10.17358/jabm.6.1.186

Efendi N. 2021. Developing of beach-based ecotourism areainthesub-districtofKelumbayan, Tanggamus regency. Jurnal Pemikiran dan Penelitian Administrasi Bisnis dan Kewirausahaan 5(3):227-239.

Erianto S, Sarma, Bastian. 2021. Karakteristik pengunjung ekowisata pesisir pantai arung buaya desa Meliah kecamatan Subi kabupaten Natuna. Jurnal Teknologi Lingkungan Lahan Basah 9(1):1-6. https://doi.org/10.26418/jhl. v9i1.45860

Hara Y, Widiastuti N, Tebaiy S. 2021. Kelayakan sungai seni kobereh sebagai obyek dan daya tarik wisata alam di distrik Mare Selatan, kabupaten Maybrat, Papua Barat. Jurnal Sumberdaya Akuatik Indopasifik 5(1): 103-112. https://doi.org/10.46252/jsai-fpik-unipa.2021. Vol.5.No.1.116

Hartati F et al. 2021. Nilai ekonomi ekowisata mangrove di desa Margasari, kecamatan Labuhan Mringgai, kabupaten Lampung Timur. Jurnal Belantara 4(1):1-10. https://doi.org/10.29303/ jbl.v4i1.449

Hedman J, Kalling T. 2003. The business model concept: Theoretical underpinnings and empirical illustrations. European Journal of Information Systems 12(1): 49-59.https://doi.org/10.1057/ palgrave.ejis. 3000446

Muller K, Omabak Y. 2014. Amungme. Indonesia: 
Lembaga pengembangan masyarakat Amungme dan Kamoro.

Osterwalder A, Pigneur Y. 2010. Business Model Generation. New Jersey: John Wiley dan Sons, inc.

Pesik MU, Lagarense BES. 2021. Pengembangan atraksi ekowisata mangrove berbasis masyarakat di kawasan pesisir desa Tateli Dua, kab. Minahasa, provinsi Sulawesi Utara. Jurnal Hospitaliti dan Pariwisata 4(1): 93-100. https:// doi.org/10.35729/jhp.v4i1.59.

Prabuwisudawan D, Rifin A, Djohar S. 2018. Strategi pengembangan balai inseminasi buatan Lembang kabupaten Bandung Barat dengan pendekatan business model kanvas. Jurnal Aplikasi Manajemen dan Bisnis 4(3)317-327. https:// doi.org/10.17358/jabm.4.3.317

Rofiq MR, Prananta R. 2021. Jenis-jenis objek ekowisata dan peran kelompok sadar wisata (pokdarwis) Nglanggeran dalam pengelolaan ekowisata di desa wisata Nglanggeran kabupaten Gunungkidul. Journal of Tourism and Creativity $5(1)$.

Simarmata MT, Marulam, Triastuti. 2021. Identifikasi potensi pemanfaatan ekowisata dan jasa lingkungan kabupaten Samosir. Jurnal Akar 10(1). https://doi.org/10.36985/jar.v10i1.469
Susanti WD, Safeyah M, Mutia F et al. 2021. Studi peluang pengembangan ekowisata untuk mendukung keberlanjutan kota (studi kasus: kelurahan Medokan Ayu, Surabaya). Jurnal Arsitektur 11(1):9-16. https://doi.org/10.36448/ ja.v11i1.1706

Syukur A et al. 2020. Potensi pengembangan ekowisata solusi matapencaharian berkelanjutan masyarakat di desa Ketapang Raya Lombok Timur. Jurnal Pengabdian Magister Pendidikan IPA 3(2): 271-280. https://doi.org/10.29303/ jpmpi.v3i2.575

Widagdyo KG. 2021. Pemasaran, daya tarik ekowisata dan minat berkunjung wisatawan. Esensi: Jurnal Bisnis dan Manajemen 7(2):261-276. https:// doi.org/10.15408/ess.v7i2.5411

Widayanto MT. 2021. Pengembangan objek wisata bukit Dami dengan konsep ekowisata di desa Tigasan Wetan, Leces, Probolinggo. Ta'awun: Jurnal Pengabdian kepada Masyarakat 1(1):99107.

Widyastutik, Panjaitan I, Malau F, Fahreiza Y. 2020. Strategi peningkatan daya saing sektor jasa pariwisata Indonesia: Studi kasus jasa pariwisata Danau Toba dan Bali. Jurnal Aplikasi Bisnis dan Manajemen (JABM) 6(2):356-368. https://doi. org/10.17358/jabm.6.2.356 